\title{
The Effect of Risk Management and Good Corporate Governance on Financial Performance and Its Impact on the Firm Value
}

\author{
Zakir Muhammad, Djayani Nurdin, Nurhayati Haris, Sulaeman Miru \\ Pascasarjana Universitas Tadulako Palu
}

\begin{abstract}
This research aims to test and prove empirically about the effect of Risk Management and Good Corporate Governance on Financial Performance and Its Impact on The firm Value [Study on Regional Venture Capital Company (PMVD) in Indonesia]. Population of this research are 27 companies of Venture Capital located in 26 Provinces, and that meet the criteria of sample are 27 companies of Venture Capital in 26 Provinces, so that total of observation analyzed to 162. Data used are statement of balance financial and income of PMVD from 2010 until 2015. Data source is from PT. Bahana Artha Ventura as mother company. Testing is done with Path Analysis. The analysis result shows that Risk Management has a significant negative effect on Financial Performance. GCG does not have a simultaneous effect on Financial Performance. Then Risk management has a significant negative effect on the Firm Value while Risk Management has a significant negative effect on the Firm Value through Financial Performance and GCG doesn't have significant effect on the Firm Value through Financial Performance.
\end{abstract}

Keywords: Risk Management. Good Corporate Governance, Financial Performance and Firm Value

\section{Introduction}

In fact, venture capital has an important role to connect financial market, provide capital for companies that have trouble finding and drawing capital. These companies are generally small-scale and newly operating, filled with high uncertainty and large differences between entrepreneur and capital investor knowledge. Furthermore, these companies usually have very few real assets and operate in a rapidly changing market.

The growth of venture capital company in Indonesia is begun with Government Regulation No. 18/1973 on State Equity Participation. Then the first venture capital company formed in Indonesia is PT Bahana Pembinaan Usaha Indonesia (BPUI), a state owned enterprises (SOEs) whose share is owned by Department of Finance $(82.2 \%)$ and Bank Indonesia (17.8\%). The first venture capital company is ever in the spotlight in financial world of Indonesia after one of its subsidiaries, PT Bahana Artha Ventura (BAV), aggressively spread business all over the province, forming a Regional Venture Capital Company (PMVD) aimed at financing small and medium enterprises (UKM).

Venture capital investment is done because there is financing opportunity in company that does not have access to obtain loans from banks, for example it does not have enough colateral, not have a name and wide relationships among the business world or not have adequate financial statements. Venture capital financing has many opportunities in developing a business world that facilitates entrepreneurs or new entrepreneurs. Indeed venture capital investment has a very high risk but the risk is balanced with the return that will be obtained by investors.

Apart from the importance of personal equity in financing and encouraging the formation of new innovative companies and in relocating capital to more productive sectors of economy is relatively little knowledge about characteristics of personal equity as an asset class in terms of liquidity, risk and return. Private equity investment is compared to other asset classes, is actually illiquid, as well as in the absence of a secondary market that supports such investments.

Risk is uncertainty about future events. Uncertainty is a condition that causes risk growth. And if it is further examined, "uncertain condition" arises for various reasons, among others; The time spacing begins planning, the limited information required, the limitation of decision maker knowledge and so on. Risk Management is a structured approach to managing threat-related uncertainty, comprising risk assessment activities, developing strategies for making risk out which appears and reducing risk using managerial resources which exists.

In 1992, Good Corporate Governance (GCG) in the first is introduced by Cadbury Committee with definition that GCG is a set of rules governing relationships among shareholders, managers, creditors, governments, employees and other parties which have an interest relating to their rights and obligations. GCG is a sound corporate principle that needs to be applied to company that is implemented solely to safeguard the interests of company to achieve the goals and objectives of company.

Venture Capital has different funding format with other financing institution such as banking. The absence of guarantees in venture capital financing causes venture capital company unable to let entrepreneur 
financed go hang without interference. Venture capital company must be confident that the invested capital is not used for things that are not related to the company's objectives in order to ensure the return (return) of their investment. In relationship between venture capital company and individual/company financed encourages the need for good governance in managing the business cooperation.

Performance measurement can be used as a measure of the success of an organization in a certain period of time and performance measurement result can be used as input for correction and improvement of organization in the future. According to IAI (2007) financial performance is company's ability to manage and control its resources. Financial ratio analysis is a financial analysis technique to know the relationship between certain posts in the balance sheet and income statements both individually and simultaneously.

One of the important indicator to see company's prospect in the future is to see how far the growth of company profitability. Weston and Copeland, (1996:2) state that profitability is the effectiveness of management shown by profits generated from sales or investment company. In this research the performance of company discussed is profitability of Return on Assets (ROA). The choice of ROA as an indicator of company performance, because this variable in some previous researches shows better performance measurement (Dodd and Chen, 1996), and ROA more represents the interests of stakeholders (Sudiyatno and Puspitasari, 2010:1-22).

This research aims to explain and analyze the effect of risk management and corporate social responsibility on Regional Venture Capital Company (PMVD).

\section{Literature Review}

\section{Investment Theory}

According to Tandelilin (2010:2), investment is a commitment to a number of funds or other resources being undertaken at the moment, with the aim of gaining some profit in the future. While Halim (2005:5) states that investment is essentially a placement of funds at the moment in hope of making a profit in the future. Generally the investment is categorized into two types namely, real assets and financial assets. Real asset is tangible like buildings, vehicles and land. While the financial asset is the indirect claims document of the holder to real assets of the party publishing the securities. Financial investment is generally done through the capital market.

\section{Agency Theory}

In business development the owner faces problems related to company management. In this condition the owner can not manage alone, consequently the responsibility of company management is delegated to the second party. This decision led to the separation of ownership and control of company between the owner as principal and manager as agent (Jensen and Meckling, 1976).

Manager gets wages and other incentives from company because they represent the owners of company in making decisions. In this case, a manager is an agent who acts on behalf of shareholder (principal). The relationship between principal and agent is called the agency relationship (Rao, 1992:27).

Agency theory focuses attention on agency problem that occurs when there is an agency relationship between the principal and the agent. In this case the principal delegates authority to agent to make a decision (Anthony and Govindarajan, 2003). Premise of agency theory is that agent behave self-interested, risk averse, rational actors who always try less effort (moral hazard) and adverse selection. This agency theory tries to solve two problems related to the agency problem, namely (1) problem of monitoring that arises because principal can not prove whether the agent has behaved appropriately; (2) problem of risk sharing, particularly in cases of outcome control that arises when principal and agent behave differently about risks (Eisenhardt 1989: 57-74).

The basic idea of agency theory management provides a new perspective on corporate governance. Company is shown as a cooperative relationship between the principal (shareholder or owner of company) and agent (management). The existence of vested interest management results in the need for check and balance to reduce the possibility of power abuse by management. Mechanism that can be done to overcome this problem is to apply Good Corporate Governance. Good Corporate Governance (GCG) is a form of good corporate management, which includes a form of protection to the interests of shareholders (public) as owner of company and creditors as external funders. A good corporate governance system will provide effective protection to shareholders and creditors to recover the investment fairly, appropriately and efficiently, and to ensure that management acts as well that can be acted for the benefit of company (The Indonesian Institute for Corporate Governance, 2006).

\section{Value of the firm}

The main purpose of company according to theory of the firm is to maximize the wealth or value of the firm (Salvatore, 2005). Maximizing value of the firm is very important for a company, because by maximizing value of the firm means also maximizing shareholder wealth that is the main purpose of company.

According to experts definition of firm value is different, the opinion of Husnan (2012:6) for 
companies that have not been "go public" firm value is a price that is willing to be paid by prospective buyer if the company is sold, while for companies that have been "go public" firm value can be seen from the existing shares value in capital market. The value of share itself is defined by the number of shares multiplied by the market value per share plus the debt value, assuming if the debt value is constant then directly increase of share value will increase the value of company.

According to Suharli (2006), there are some common approaches to assess the company, among them: (1) Profit Approach, namely, method of earning ratio ratio or Price Earning Ratio. (2) Cash flow approach includes the discounted cash flow method. (3) Devidend approach includes the method of dividend growth. (4) Asset approach includes asset valuation method. (5) Stock price approach. (6) Economic Value Added (EVA) Approach.

\section{Types of Research}

\section{Research Method}

The type of this research is descriptive research and verification research. Descriptive research relates to data collection to give description about Risk Mananagement and God Corporate Governance and Financial Performance of Regional Venture Capital Company (PMVD) in Indonesia, while Verification research is a research testing hypothesis to know the effect of Risk management and Good Corporate Governance on Financial Performance and its impact on the Value of PMVD Companies in Indonesia.

\section{Population, Sample and Sampling Technique}

Sample population is a generalization area consisting of objects/subjects that have certain qualities and characteristics set by researcher to be studied and then drawn conclusions. So population is not just people, but also objects and other natural objects. Population is also not just the number of objects/subjects studied, but includes all characteristics/properties possessed by the subject or object (Sugiono, 2014:61). In this research the population of research is PMVD in Indonesia which amounts to 27 companies. Sample is everything that is made into unit which will be the object of research (Somantri and Muhidin, 2006:45). The number of PMVD samples researched amounted to 27 companies. The following table:

Table 1 Names of Regional Venture Capital Companies

\begin{tabular}{|c|c|c|c|}
\hline .No. & PMVD & Built in & Province \\
\hline 1. & Venture West Java Facility & October 28,1993 & West Java \\
\hline 2. & Venture North Sumatra Facility & September, 231994 & North Sumatra \\
\hline 3. & Venture East Java Facility & October 05,1994 & East Java \\
\hline 4. & Venture Central Java Facility & November 26, 1994 & Central Java \\
\hline 5. & Venture Jogyakarta Facility & November 26, 1994 & D.I. Jogyakarta \\
\hline 6. & Venture South Sulawesi Facility & December 01, 1994 & South Sulawesi \\
\hline 7. & Venture Bali Facility & December 10,1994 & Bali \\
\hline 8. & Venture Surakarta Facility & April 26, 1995 & Central Java/Solo \\
\hline 9. & Venture Lampung entura & May 08, 1995 & Lampung \\
\hline 10. & Venture South Sumatra Facility* & May 18,1995 & South Sumatra \\
\hline 11. & Venture West Sumatra Facility & May 28,1995 & West Sumatra \\
\hline 12. & Venture West Kalimantan Facility & June 21,1995 & West Kalimantan \\
\hline 13. & Venture East Kalimantan Facility & July 01, 1995 & East Kalimantan \\
\hline 14. & Venture Jambi Facility & July 04, 1995 & Jambi \\
\hline 15. & Venture Aceh Facility & July 27,1995 & Daerah Istimewa Aceh \\
\hline 16. & Venture North Sulawesi Facility & October 27, 1995 & North Sulawesi \\
\hline 17. & Venture NTB Facility & December 05, 1995 & West Nusa Tenggara \\
\hline 18. & Venture Papua Facility & April 11, 1996 & Papua \\
\hline 19. & Venture Maluku Facility** & 12 April 1996 & Maluku \\
\hline 20. & Venture Riau Facility & July 23, 1996 & Riau \\
\hline 21. & Venture Southeast Facility & October 30,1997 & Southeast Sulawesi \\
\hline 22. & Venture Central Sulawes Facility & March 25, 1997 & Central Sulawesi \\
\hline 23. & Venture Central Kalimantan Facility & May 08, 1997 & Central Kalimantan \\
\hline 24. & Venture South Kalimantan Facility & September 06, 1997 & South Kalimantan \\
\hline 25. & Venture Bengkulu Facility & December 20, 1997 & Bengkulu \\
\hline 26. & Venture NTT Facility & January 22, 1998 & East Nusa Tenggara \\
\hline 27. & MVI / Jakarta Facility & February 05,1998 & DKI Jakarta \\
\hline
\end{tabular}

- Information : * Liquidation process ; **NPI above $50 \%$

\section{Operationalization of Variables}

In path analysis model known two types of variables are exogenous variable and endogenous variable. Exogenous variable gives direct or indirect effect on endogenous variable. While endogenous variable is a variable that can give effect other endogenous variable.

In accordance with the framework of thinking that has been developed, the exogenous variables in this research are Risk Management (X1) and Corporate Governance (X2), while endogenous variables are Financial 
Performance (X3) and Firm Value (Y).

Operational definition is a definition given to a variable or a constraint by means of giving meaning, or specifying an activity, or providing an operational given to measure the constituent or vaiabel (Moh Nazir, 2009:126). Description of variables operationalization in this research are as follows:

1. Firm Value (Y)

a. Conceptual definition

Firm value is the amount of cost that a prospective buyer is willing to pay if the company is sold.

b. Operational definition

Firm value is the value of Altman Zscore which is a variable to measure the potential of bankruptcies obtained from the sum of multiplication results of a certain constant value each with 5 elements of ratio those are: Working Capital divided by Total Asset, Profit held divided by Total Asset, Profit before tax interest divided by Total Asset, Share book value divided by book value, Total Debt and Total Long Term Investment and Short Term divided by Total Asset.

\section{Financial Performance (X3)}

a. Conceptual definition

Financial Performance is determination of certain measures that can measure the success of an organization or company in generating profit (Sucipto, 2003).

b. Operational definition

Financial performance is a measure of organizational achievement in financial field. In this research measure of financial performance is represented by performance of profitability. Profitability includes: Return on Asset (ROA), Return on Equity (ROE), Residual Income, and Economic Value Added (EVA). In this research the profitability measure selected is ROA.

$$
\mathrm{ROA}=\frac{\text { Net Income after Tax }}{\text { Average Total Assets }}
$$

\section{Risk Management (X1)}

a. Conceptual Definition

Risk management is a set of policies, comprehensive procedures that an organization owned for managing, monitoring and controlling risk that may arise.

b. Operational definition

The research object in this research is a venture capital company which risk is potential loss due to the occurrence of certain events which include market risk, liquidity risk, operational risk, and credit risk (financing), especially Non proforming Investment (NPI) become the measure of this research

\section{Corporate Governance (X2).}

a. Conceptual Definition

Good Corporate Governance (GCG) is a system that regulates and controls companies expected to provide and increase Firm value to shareholders.

b. Operational definition

GCG mechanism is characterized by institutional ownership, management ownership, presence of audit committee and independent commissioner. So operationalization variable of corporate governance is: Value of institutional share ownership

\subsection{Types and Data Sources}

The type of data in this reseasrch is secondary data. Secondary data can be financial report data, report of advocacy and coaching resources for Business partner company (PPU), and other reports related to the discussion in this research owned by PMVD period 2010-2015. Sources of data in this research are:

1. PT.Bahana Artha Facility as Mother Company is as the source of PMVD financial report data.

2. Regional Venture Capital Company related to the ownership of financial report data, Collectibility report of Financing/Investment (NPI) from Business partner company (PPU), GCG mechanism and other reports related to the discussion in this research.

\section{Inferential data analysis.}

Path analysis is a technique of statistical analysis developed from multiple regression analysis. In regression model, model formed is used to predict endogenous variables if the exogenous variables are known. While in path analysis, model formed is used to explain the magnitude of effect (not predicting) of exogenous variable on endogenous variable. 
In path analysis there are two analysis methods, namely decomposition method and trimming method. If the objective of the research is to form a causal model that inserts all observed variables then decomposition method is used. While trimming method is used to improve a model of path analysis structure by removing exogenous variables whose path coefficients are not significant.

The application of path analysis using Firm Value (NP) data results in a causal model of NP formed due to causal influences affecting the structure within the model. This analysis is based on the effect model among variables to know the effect of Risk Management (RM), Good Corporate Governance (GCG) and Financial Performance (KK) on NP.

1. Path Analysis

\section{Result And Discussion}

A. Direct Effects

a. Direct effects of Risk Management on financial performance.

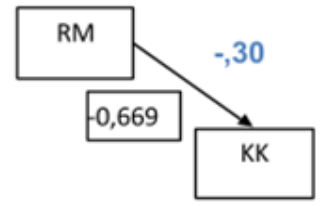

Direct Effects (Group number 1 - Default model)

\begin{tabular}{|l|l|l|l|}
\hline & $\mathrm{x} 2$ & $\mathrm{x} 1$ & $\mathrm{Y}$ \\
\hline $\mathrm{y}$ &, 015 &,- 303 &, 000 \\
\hline $\mathrm{z}$ &,- 324 & $-3,166$ & 20,725 \\
\hline & & & \\
\hline
\end{tabular}

Standardized Direct Effects (Group number 1 - Default model)

\begin{tabular}{|l|l|l|l|}
\hline & $\mathrm{x} 2$ & $\mathrm{x} 1$ & $\mathrm{y}$ \\
\hline $\mathrm{y}$ &, 026 &,- 669 &, 000 \\
\hline $\mathrm{z}$ &,- 015 &,- 185 &, 548 \\
\hline
\end{tabular}

Based on the result of AMOS output in Table 4.9 it is obtained the coefficient value of path of 0.30 with $\mathrm{P}$ value of 0.000 or $\mathrm{P}<0.05$ Thus Risk management $(\mathrm{RM})$ has a significant negative effect on Financial Performance the better of RM the better of PMVD Financial Performance, Thus the first hypothesis stating that Risk Management has a significant effect on PMVD Financial Performance based on the result proved. The direct effect of RM on KK., According to existing standardized data of (-) 0.669.

b. The direct effect of Good Corporate Governance on Financial Performance.

c.

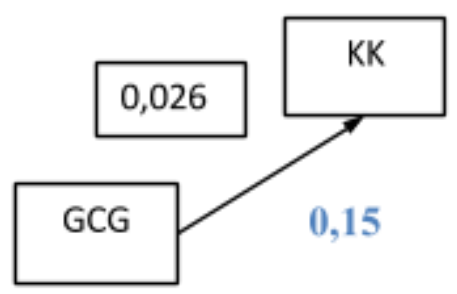

Direct Effects (Group number 1 - Default model)

\begin{tabular}{|l|l|l|l|}
\hline & $\mathrm{x} 2$ & $\mathrm{x} 1$ & $\mathrm{Y}$ \\
\hline $\mathrm{Y}$ &, 015 &,- 303 &, 000 \\
\hline $\mathrm{Z}$ &,- 324 & $-3,166$ & 20,725 \\
\hline
\end{tabular}

Standardized Direct Effects (Group number 1 - Default model)

\begin{tabular}{|l|l|l|l|}
\hline & $\mathrm{x} 2$ & $\mathrm{x} 1$ & $\mathrm{y}$ \\
\hline $\mathrm{Y}$ &, 026 &,- 669 &, 000 \\
\hline $\mathrm{Z}$ &,- 015 &,- 185 &, 548 \\
\hline
\end{tabular}

From the result above it shows the coefficient value of this path is 0.015 with a $\mathrm{P}$ value of 0.666 or 
$\mathrm{P}>0.05$, or not significant thus the Good Corporate Governance (GCG) doesn't have effect on financial performance of PMVD, so the second hypothesis There is a significant direct effect on Financial performance is not proven. The magnitude of GCG direct effect on financial performance to 0.026 (standardized).

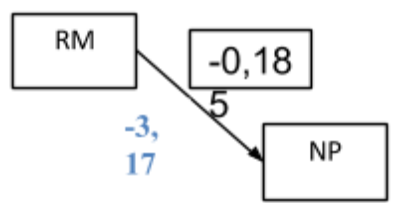

d. Direct Effect of Risk Management on the Value of PMVD Companies.

Direct Effects (Group number 1 - Default model)

\begin{tabular}{|l|l|l|l|}
\hline & $\mathrm{x} 2$ & $\mathrm{x} 1$ & $\mathrm{y}$ \\
\hline $\mathrm{y}$ &, 015 &,- 303 &, 000 \\
\hline $\mathrm{z}$ &,- 324 & $-3,166$ & 20,725 \\
\hline & & & \\
\hline
\end{tabular}

Standardized Direct Effects (Group number 1 - Default model)

\begin{tabular}{|l|l|l|l|}
\hline & $\mathrm{x} 2$ & $\mathrm{x} 1$ & $\mathrm{y}$ \\
\hline $\mathrm{y}$ &, 026 &,- 669 &, 000 \\
\hline $\mathrm{z}$ &,- 015 &,- 185 &, 548 \\
\hline
\end{tabular}

From the result it shows that coefficient value in this path is 3.166 with $\mathrm{P}$ value 0.017 or $\mathrm{P}<0.05$, hence Risk management (RM) has negative and significant effect on Firm Value. This means that the smaller of RM the better of Firm Value. So the third hypothesis There is a significant direct effect of RM on NP proven. Stadardized direct effect RM on NP by (-) 0.18 .

e. Direct Effect of Risk Management on the Value of PMVD Companies.

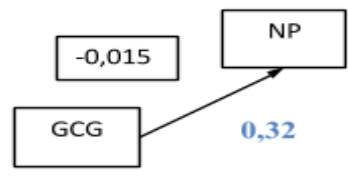

Direct Effects (Group number 1 - Default model)

\begin{tabular}{|l|l|l|l|}
\hline & $\mathrm{x} 2$ & $\mathrm{x} 1$ & $\mathrm{y}$ \\
\hline $\mathrm{y}$ &, 015 &,- 303 &, 000 \\
\hline $\mathrm{z}$ &,- 324 & $-3,166$ & 20,725 \\
\hline & & & \\
\hline
\end{tabular}

Standardized Direct Effects (Group number 1 - Default model)

\begin{tabular}{|l|l|l|l|}
\hline & $\mathrm{x} 2$ & $\mathrm{x} 1$ & $\mathrm{y}$ \\
\hline $\mathrm{y}$ &, 026 &,- 669 &, 000 \\
\hline $\mathrm{z}$ &,- 015 &,- 185 &, 548 \\
\hline
\end{tabular}

The result shows that coefficient value in this path is 0.324 , with $\mathrm{P}$ value 0.796 or $\mathrm{P}>0.05$, it means that not significant so the fourth hypothesis there is a significant direct effect of GCG on Firm Value (NP) is not proven, and the stadardized direct effect of GCG on NP by (-) 0.015 .

\section{f. Direct effect of Financial Performance on Firm Value.}

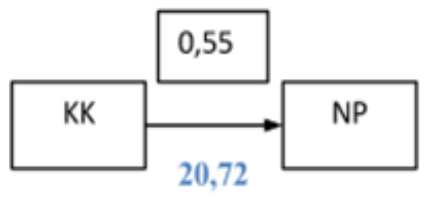

Direct Effects (Group number 1 - Default model) 


\begin{tabular}{|l|l|l|l|}
\hline & $\mathrm{x} 2$ & $\mathrm{x} 1$ & $\mathrm{y}$ \\
\hline $\mathrm{y}$ &, 015 &,- 303 &, 000 \\
\hline $\mathrm{z}$ &,- 324 & $-3,166$ & 20,725 \\
\hline & & & \\
\hline
\end{tabular}

\section{Standardized Direct Effects (Group number 1 - Default model)}

\begin{tabular}{|l|l|l|l|}
\hline & $\mathrm{x} 2$ & $\mathrm{x} 1$ & $\mathrm{y}$ \\
\hline $\mathrm{y}$ &, 026 &,- 669 &, 000 \\
\hline $\mathrm{z}$ &,- 015 &,- 185 &, 548 \\
\hline
\end{tabular}

Based on the result shows the coefficient value of this path is 20.725 with $\mathrm{P}$ value 0,000 or $\mathrm{P}<0.05$, Thus, Financial Performance has a significant positive effect on Firm Value. It means the better of Financial Performance the better of Firm Value. Thus the fifth hypothesis which states that Financial Performance has a significant positive effect on Company Value is proven. With the magnitude of Stadardized direct effect of Financial Performance on Firm Value by 0.548.

\section{B. Indirect Effects.}

To know indirect effects, hence based on path analysis result, can be seen in following table:

Table 4.10 Indirect effects

Indirect Effects (Group number 1 - Default model)

\begin{tabular}{|l|l|l|l|}
\hline Variabel & $\mathrm{x} 2(\mathrm{GCG})$ & $\mathrm{x} 1(\mathrm{RM})$ & $\mathrm{Y}(\mathrm{KK})$ \\
\hline $\mathrm{Y}(\mathrm{KK})$ &, 000 &, 000 &, 000 \\
\hline $\mathrm{Z}(\mathrm{NP})$ &, 304 & $-6,273$ &, 000 \\
\hline
\end{tabular}

Based on the table it can be explained as follows:

a. A. Risk Mananagement (RM) through Financial Performance (KK) to Firm Value (NP).

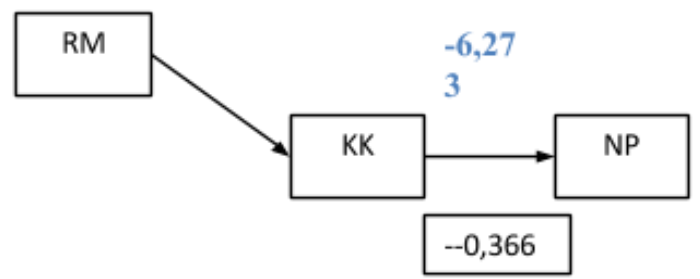

Standardized Indirect Effects (Group number 1 - Default model)

\begin{tabular}{|l|l|l|l|}
\hline & $\mathrm{x} 2$ & $\mathrm{x} 1$ & $\mathrm{y}$ \\
\hline $\mathrm{y}$ &, 000 &, 000 &, 000 \\
\hline $\mathrm{z}$ &, 014 &,- 366 &, 000 \\
\hline
\end{tabular}

From the result shows the coefficient value of this path is -6.723 with a value of $\mathrm{P} 0.000$ or $\mathrm{P}<0.05$ thus the RM has a significant negative effect on Firm Value, It means the better of RM then the Firm Value will also be better, and the magnitude of indirect effect (Standardized) is (-) 0.366.

b. The effect of Good Corporate Governance (GCG) on Firm Value (NP) through Financial Performance (KK)

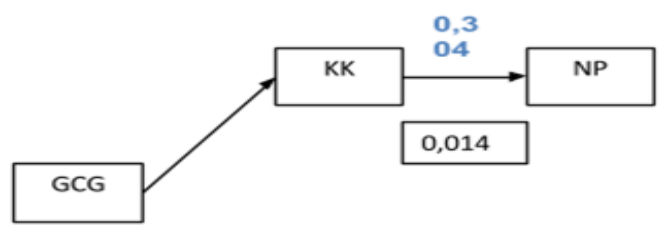

Standardized Indirect Effects (Group number 1 - Default model)

\begin{tabular}{|l|l|l|l|}
\hline & $\mathrm{x} 2$ & $\mathrm{x} 1$ & $\mathrm{y}$ \\
\hline $\mathrm{y}$ &, 000 &, 000 &, 000 \\
\hline $\mathrm{z}$ &, 014 &,- 366 &, 000 \\
\hline & & & \\
\hline & & & \\
\hline
\end{tabular}

From the result shows the coefficient value in this path is 0.304 with a value of $\mathrm{P} 0.796$ or $\mathrm{P}>0.05$, 
thus GCG through Financial Performance doesn't have a significant effect on Firm Value. The magnitude of indirect effect of GCG on Firm Value through financial performance (standardized) is 0.14.

\section{The Effect of Risk Management on Financial Performance}

Based on the results of this research it shows the effect is significant, negative that is not unidirectional between risk management (NPI) and financial performance (ROA) which means that the smaller the NPI, the greater ROA obtained by PMVD, This is in line with the finding of Adeusi et al (2014) That better management of risk management results in better financial performance of banks while according to Olamide et al (2015), that Risk Management does not always lead to positive financial performance of bank, although effective risk management in financial institutions reduces systemic and economic damage but it does not guarantee an increase in equity yield. And finding of Atar et al (2014); Implementation of credit risk management affects the financial performance of banks. It is known that the income source of PMVD is from investment to Business partner company either in the form of financing with profit sharing pattern or in the form of equity participation, if the condition of financing is healthy in which PPU can timely pay the obligation to return principal loan and timely profit sharing every periodic that is appropriate with the agreement of financing agreed between PMVD and PPU.

Timely repayment of principal payment from PPU can be rolled back to CPPU or other PPU. Profit sharing is the earning/income of PMVD used for overhead and the rest into company Profit. The healthier condition of NPI Financing will have a positive impact on PMVD Financial Performance and will be multiplier effect on the income from financing rolling on to other PPU, otherwise if the high NPI financing condition will crush the source of income that gives impact to the decreasing financial performance.

\section{The effect of Good Corporate Governance on financial performance}

Based on this research, the effect of GCG on financial performance is not significant. This is in line with Hastuti's research (2005), which found that there is no significant relationship between ownership structure and company's financial performance, Permatasari and Novitasary (2014), found that the GCG composite value variable does not give directly effect on the financial performance (ROE). Vary with Todorovic (2013); Maher and Anderson (1999) that GCG gives effect on company's financial performance. GCG in this research is institutional shareholding (shareholder) that tends to be non-operational or represented in the structure of Commissioners body (Board of Commissioners) of PMVD, referring to the policy of Financial Services Authority (OJK) in Indonesia, limiting the movement of Board of Commissioners limited to provide directions, Help to make operational strategic policy of PMVD while the implementation is fully submitted to the Board of Directors of PMVD to run it, however in act of Limited Liability Company (PT), it is mentioned that Board of Commissioners may be given the authority regulated in statutes of company without the approval or assistance of the Board of Commissioners, the right doing Conducted by the Board of Directors shall remain binding on the Company. In this position the premise of agency theory applies that an agent can lead to agency problem, because once authority has been delegated to the agent to make a decision at this point the issue will arise. For that intense supervision, which is inserted in procedure and adequate system and then supported by the commitment and integrity of the Board of Directors as PMVD managers can improve the financial performance of PMVD.

\section{The Effect of Risk Management on Firm Value.}

The result of this research indicates that the effect of risk management on company value is not significant. This is in line with research of Rumondor et al (2015) Company Risk has a negative and not significant effect on Corporate Value, vary with McShane et al (2011) found that there is a positive relationship between ability increase of Traditional risk with Firm Value, while Tahir and Razali (2011) found that the Company's Risk Management has a positive and significant effect on Firm Value. It can be explained that if risk management (NPI) increases then the Firm value will decrease, otherwise if the NPI decreases then Firm value will rise. Risk management (NPI) is a healthy quality of a financing to PPU in PMVD, which is included in category of NPI is (sum of non-current financing + doubtful financing + truble financing), Investment is a commitment to a number of funds or other resources being undertaken at this time with the aim of obtaining some future benefits (Tandelilin, 2010). If investment invested for the purpose of obtaining profit is not obtained then this will turn into risk. Because the risks as a possibility to get a lower profit than expected profit or will not receive anything from the Investment (Poon et al, 1992). Thus, a low NPI can also influence the Firm Value to be high.

\section{The Effect of Good Corporate Governance on Firm Value}

The result of this research indicates that the effect of good corporate governance (GCG) is not significant on Firm Value, this indicates that the institutional shareholders (GCG) does not result in up or down 
the Firm Value. This is in line of OJK policy at bank and non bank financial institutions to do the duties division of Supervision and operations of companies in which the position of shareholder which is usually represented on the board of commissioners can not perform direct operational duties on the running of company. Vary with the findings of Randy and Juniarti (2013), which means that if the value of GCG rises then the Firm Value will also rise. The results of this research in line with the finding of Retno M and Priantinah (2012), and Wardoyo and Veronica (2015) found that GCG has a significant positive effect with Firm Value. It can be explained that the shareholder role as a variable of GCG researched can oversee the agent, with simple questions such as: 1) Can the company pay interest and loan installments?, 2). Does the company get a return on invested capital ?, 3) Is the company effective in using debt financing and is the cost in supervision control?, 4). Does the company market experience the growth or decrease and are the changes that occur opportunities and threats?. These examples of such questions are part of duties and control functions of shareholder to assess whether the company's performance is working as expected or in accordance with the Annual Work Plan and Budget (RKAT), annually. The result achieved is the answer to the company's performance, which is also certainly a financial performance that gives impact on Firm Value. Firm Value is the price that is willing to be paid by prospective buyers if the company is sold while for companies that have been "go public" the Firm value can be seen from the value of shares in stock market. And PMVD is a company that have not been "go public".

\section{The Effect of Financial performance on Firm Value.}

Based on the result of this research showed that financial performance has significant effect on Firm Value. Result of this research is in line with Wardoyo and Veronica (2013), Mahendra Dj et al (2012), Pertiwi and Ika Pratama (2012), found that financial performance has significant effect on Firm Value, This can be explained that if financial performance of ROA increased then it gives impact on Firm Value which also increased.

An analysis of PMVD financial performance condition to explore information relation to objectives, profitability, efficiency and risk level. This can be obtained from financial ratios sourced from PMVD financial report, namely: Balance Report, Income Statement and Cash Flow Statement. In financial performance variable is used Return On Asset abbreviated ROA that is ratio that divides between net profit after tax with average assets at the beginning and the end of period. This ratio is used to see the ability of PMVD in managing each asset value owned to generate net profit after tax. The higher of ROA value of a PMVD the better of PMVD's ability to manage its assets. And a final impact on the increase osf PMVD Firm Value intended.

The indirect effect of Risk Management (RM) on Firm Value (NP) through Financial Performance (KK).

The result of this research shows that the effect of RM on NP through KK in total has positive effect. KK which increases will affect NP which is getting better or increased, but the problem is in RM if RM is negative or increase then KK will decrease so that if RM is well managed, starting with the initial selection of Business Partner Company (PPU) which really have future prospect and manager must have a high integrity and adhere to business plan that has been agreed early and managed with good management which will result in all the financing which will be healthy and able to pay the obligation for profit sharing and the principal on time, which is a source of PMVD income thus it will have an impact on increasing of ROA so KK will be better on the contrary if RM is increased or not managed well it will decrease KK and eventually NP will decrease.

\section{The indirect effect of Good Corporate Governance (GCG) on Firm Value (NP) through Financial Performance (KK).}

The result of this research shows that the indirect effect of GCG on NP through KK. In total its effect is positive and the problem on path of GCG to KK is negative so that the Institutional Shareholder needs to do is to affirm to the Board of Commissioners as shareholder representatives to conduct intense supervision and coaching to PMVD manager and will have an impact to good financial performance also and result in Firm Value will also be high. Although PMVD Firm Value assessed uses the Altman Zscore Model approach varies and it is seen from grouping of category 1 to 4 grouped based on the total value of existing assets entering the gray and bankrupt areas this shows that it is true that venture capital company finance projects or Businesses with high risk level and the company usually lack adequate assets, lack of market access and also a one man show, most of PPU financed is Small Enterprises and Micro Enterprises in the category intended, Naturally, The Altman Zscore model detects the condition of Firm Values of PMVD which is in the position of the Gray and the bankrupt areas, this is because the PMVD does financing to PPU or a business that has a high Risk. PMVD mostly still survive because it still maintains the level of efficiency in management of its business. Efficiency level can be seen from BOPO ratio that is ratio of Operational Cost to Operational Income, if BOPO is smaller then it means efficiency is achieved. If efficiency can be achieved then financial performance of ROA also will grow and increase so that the PMVD Firm Value will grow and increase also. However, in this research, PMVD has not set the standard of BOPO Ratio which is used as a reference in business management to realize the 
Work Plan and Annual Budget by PMVD manager, if this is applied it will have an impact on the better financial performance and also impact on the Firm Value getting better .

\section{Novelty}

Novelty is a requirement in dissertation writing, based on previous research results which have been discussed and described in chapter 2 on Risk Management, Good Corporate Governance, Financial Performance and Firm Value, then the novelty in this research is as follows:

1. Novelty of this research found that PMVD has not set a reference to the efficiency ratio of Operating Cost compared to Operating Income. If this ratio is set, each PMVD will adjust the percentage of total operating costs based on operating income in the arranging of Work Plan and Corporate Budget (RKAP) per year.

2. Novelty Variable of research that discusses jointly Risk Management, Good Corporate Governance, Financial Performance to Firm Value has not existed in previous research.

3. Novelty of research on industry of Venture Capital Company especially is in Regional Venture Capital Company in Indonesia.

\section{Conclusion And Suggestion}

Based on the results of research and analysis conducted by researcher on the effect of risk management, good corporate governance on financial performance and its impact on corporate value [study on Regional Venture Capital Company (PMVD) in Indonesia] period of 2010 - 2015, concluded that Risk management has a direct negative significant effect on Financial Performance, Good Corporate Governance has no significant effect on Financial Performance, Risk management has a significant negative effect on Firm Value, Good Corporate Governance doesn't have a significant effect on Firm Value, Financial Performance has a significant and positive effect on Firm Value, and risk management has a significant effect on Firm Value through Financial Performance and Good Corporate Governance doesn't have significant effect on Firm Value through Financial Performance.

In addition, from the results of research, the suggestion that can be given is the first Risk Management control (NPI) should be started on initial selection of Business Partner Company Candidates (CPPU) to be funded, not limited to business prospects but character, integrity and commitment of PPU It is necessary to be concerned by the Board of Directors in selecting (CPPU), in order to obtain certainty of moral obligation on business management and business risk to be faced in the future; The second Duties and Function of Supervision/control from shareholder must be intense and sustainable not only at RUPS but it is conducted by Board of Commissioner as an extension of shareholder quarterly by studying the results achieved and discussed transparently with Director/agent; The third Financial Ratio is an effective monitoring tool to assess the results achieved, but needs stermining a range/ limit of efficiency ratio which is the ratio of comparison between operational costs and operating income, so that Director/agent knows and maintains operational cost efficiency, to achieve an adequate profit; The fourth in addition to the effect of Risk Management, Good Corporate Governance and Financial Performance on Firm Value, it is necessary to consider other non-financial factors that there is a possibility of improving the quality of human resources both staff and employees, especially Business Partner Company need to be given the appropriate training and needed in the effort of increase in Firm Value and Paying attention to PMVD which has reached 2.5 decades, then forming of cadres becomes important and keep the spirit of Venture Capital to work professionally, loyal and integrity as well as sincere for the progress of business partner/Business Partner Company (PPU).

\section{Limitation of Research.}

The research undertaken is still limited to know the direct and indirect effect of Risk Management, Good Corporate Governance on Financial Performance and Its Impact on Firm Value. To complete this study it is suggested to the next researcher to equip with other Non Financial Variables.

\section{References}

[1] Adams, R. B., Hermalin, B. E., Weisbach, M. S., (2010), The role of boards of directors in corporate governance: A conceptual framework and survey. Journal of Economic Literature 48, pp. 58-107.

[2] Adeusi, Stephen Oluwafemi., Akeke, Niyi Israel., Adebisi, Obawale Simeon., dan Oladunjoye, Olawale. (2014). Risk Management and Financial Performance of Banks in Nigeria. European Journal of Business and Management, Vol.6, No.31, 2014

[3] Adisaputro, Gunawan dan Anggraini, Yunita. (2007). Anggaran Bisnis, Analisis, Perencanaan dan pengendalian laba, Yogyakarta: UPP STIM YKPN

[4] Al-Rawi, K., Kiani, R., dan Vedd, RR, (2008). The Use of Altman Equation for Bangkruptcy Prediction in an Industrial Firm, International Business and Economics Research Journal, July 2008

[5] Altman, EI, (1968). Financial Ratios, Discriminant Analysis and the Prediction of Corporate Bangkruptcy, Journal of Finance, September 1968

[6] Anthony, Robert dan Govindarajan, Vijay. (2003). Management Control System. 11th Edition: Irwin McGraw Hill

[7] Attar, Dini., Islahuddin dan M. Shabri. (2014). Pengaruh Penerapan Manajemen Risiko Terhadap Kinerja Keuangan Perbankan yang Terdaftar di Bursa Efek Indonesia. Jurnal Akuntansi Pascasarjana Universitas Syiah Kuala Volume 3, No. 1, February 2014 
[8] Brigham, E.F. dan Gapenski, L.C. (2006). Intermediate Financial Management. 7th edition. Sea Harbor Drive: The Dryden Press

[9] Bygrave, William D andJ effrey A. Timmons, (1992). Venture Capital at the Crossroads, Harvard Business Press

[10] Cremers, K. J. M., Nair, V. B., Wei, C., (2007). Governance mechanisms and bond prices. Review of Financial Studies 20

[11] Daniri, Mas Achmad. (2005). Good Corporate Governance. Jakarta: Ray Indonesia

[12] Danoshana, S. dan Ravivathani, T. (2013). The impact of the corporate governance on firm performance: A study on financial institutions in Sri Lanka. Merit Research Journal of Accounting, Auditing, Economics and Finance Vol. 1(6) December, 2013, pp. 118-121,

[13] Demb, A., Neubauer, F. F., (2012). The Corporate Board: Confronting the Paradoxes. New York, NY: Oxford University Press

[14] Djojosoedarso, S. (1999). Prinsip-Prinsip Manajemen Risiko dan Ansuransi. Jakarta: Salemba Empat.

[15] Dodd, J.L and Chen. (1996). EVA: A New Panacea Business and Economic Review, July-September : 26-28.

[16] Eisenhardt. (1989). Agency theory: An Assessment and Review. Academy of Management Review. Vol. 14 No. 1. Pp: 57-74.

[17] Fahmi, Irham. (2012). Pengantar Pasar Modal. Bandung: Alfabeta

[18] Faizal. (2004). Analisis Agency Costs, Struktur Kepemilikan dan Mekanisme Corporate Governance, Simposium Nasional Akuntansi VII Denpasar-Bali. pp. 197-207

[19] Federation of European Risk Management Associations. (2003). A Risk Management Standard. London: FERMA

[20] Frimpong Stephen., Djan, Ohene George., Bawuah, Jonas., Halidu, Osman Babamu., dan Kuutol, Peter Kwame. (2015). Impact of Corporate Governance Mechanisms and Banks Performance: Ghana's Position. International Journal of Empirical Finance. Vol. 4, No. 5, 2015, 324-335

[21] Fuller, R.J. and Farrel, J.L. Ir., (1987), Modern Investment and Security Analysis, McGraw-Hill International Editions

[22] Gompers, P.A. and Lerner, J. (2001). The Venture Capital Revolution. Journal of Economic Perspectives, 15(2), 145-168.

[23] Ghozali, Imam(2005), Aplikasi Analisis Multivariate dengan Program SPSS, Badan Penerbit Universitas Diponegoro,Semarang.

[24] Haikal, Shalahuddin, (2006). Pemberdayaan UKM atau Pemberdayaan Perusahaan Modal Facility? disampaikan pada Rapat Kerja Asosiasi Modal Facility Daerah, Samarinda Juni 2006. Tidak dipublikasikan.

[25] Halim, Abdul. (2005). Analisis Investasi, Edisi 2, Jakarta: Salemba empat

[26] Hanafi, Mamduh M. (2009). Manajemen Risiko. Yogyakarta: Sekolah. Tinggi Ilmu Manajemen YKPN.

[27] Hanafi, Mamduh M dan Abdul Halim. (2009). Analisa Laporan Keuangan. Yogyakarta: UPP STIM. YKPN.

[28] Hastuti, Theresia Dwi. (2005). Hubungan Antara Good Corporate Governance dan Struktur Kepemilikan Dengan Kinerja Keuangan (Studi Kasus pada Perusahaan yang listing di Bursa Efek Jakarta). SNA VIII Solo, $15^{\text {th }}-16^{\text {th }}$ September 2005

[29] Heinrich, Carolyn J. (2015). The Role of Performance Management in Good Governance and Its Application in Public Education. Employment Research 22(3): 4-6

[30] Husnan, Suad. (2012). Teori dan Penerapan (Keputusan Jangka Panjang). Edisi Keempat. Yogyakarta: BPFE.

[31] Husnan, Suad. (2000). Manajemen Keuangan Teori dan Penerapan. Yogyakarta: BPFE

[32] Husnan, Suad. (1985). Dasar-dasar Teori Portofolio dan Analisis Sekuritas. Yogyakarta: Unit Penerbit dan Percetakan AMP YKPN

[33] Ikatan Akuntan Indonesia (IAI). (2007). Standar Akuntansi Keuangan . Edisi 2007. Jakarta: Penerbit : Salemba Empat

[34] Jensen, M., dan Meckling, W., (1976), Theory of the firm: managerial behaviour, agency costs and ownership structure. Journal of Financial Economics, pp. 305-360

[35] Jogiyanto. (2013). Teori Portofolio dan Analisis Investasi. Edisi Ketujuh. Jakarta: BPFE

[36] Jumingan, (2006). Analisis Laporan Keuangan, Cetakan Pertama, Jakarta: PT Bumi Aksara

[37] Kadir, (2010). Statistik, Jakarta: Rosemata Sampurna

[38] Kezner, H. (1995). Project Management A System Approach to Planning Scheduling and Controlling. Fifth edition. New York : Van Nostrand Reinhold.

[39] Kumari, Neeraj. (2011). Balanced Scorecard for Superior Organizational Performance. European Journal of Business and Management, Vol 3, No.5, 2011

[40] Kusnendi,(2008). Model-Model Persamaan Struktural: Satu Dan Multigroup Sampel Dengan Lisrel, Cetakan Pertama,Alfabeta,Bandung.

[41] Laksana, Jaya. (2015). Corporate Governance dan Kinerja Keuangan (Studi Kasus Pada Perusahaan Perbankan yang Terdaftar di BEI periode 2008-2012). E-jurnal Akuntansi Universitas Udayana 11.1 (2015): 269-288

[42] Lestari, Rini. (2013). Pengaruh Manajemen Risiko Terhadap Kinerja Organisasi (Studi pada Dana Pensiun Pemberi Kerja di Wilayah Jabar-Banten). Jurnal Riset Akuntansi dan Bisnis Vol 13 No . 2 / September 2013

[43] Li Ching Chun,(1975), Path Analysis a Primer, The Bboxwood Press,California.

[44] Ljungqvist, A. and Richardson, M. (2003). The Cash Flow, Return and Risk Characteristics of Private Equity. National Bureau of Economic Research, Working Paper 9454.

[45] Mahendra Dj, Alfredo., Luh Gede Sri Artini dan A.A Gede Suarjaya. (2012). Pengaruh Kinerja Keuangan Terhadap Nilai Perusahaan Pada Perusahaan Manufaktur di Bursa Efek Indonesia. Jurnal Manajemen, Strategi Bisnis, dan Kewirausahaan Vol. 6, No. $2^{\text {nd }}$ Agustus 2012

[46] Maher, Maria dan Andersson, Thomas. (1999). Corporate Governance: Effects on Firm Performance and Economic Growth. Organisation for Economic Co-operation and Development (OECD), 1999

[47] Mahsun, Mohamad, (2006). Pengukuran Kinerja Sektor Publik,. Yogyakarta: Penerbit BPFE

[48] McShane, Michael K., Anil Nair dan Elzotbek Rustambekov. (2011). Does Enterprise Risk Management Increase Firm Value? Journal of Accounting, Auditing \& Finance 26(4) 641-658.

[49] Miller, Randall. (2013). Turning risk into results. How leading companies use risk management to fuel better performance. Americas Risk Partner EY

[50] Mulyadi, (2001), Akuntansi Manajemen : Konsep, Manfaat dan Rekayasa, Edisi. Ketiga. Jakarta: Salemba Empat

[51] Nahrowi Djalal,(2015), Pendekatan Populer dan Praktis Ekonometrika Untuk Analisis Ekonomi dan Keuangan, Fekon, Universitas Indonesia.

[52] Nasution, S. (2007). Metode Research (Penelitian Ilmiah). Jakarta: Bumi Aksara, p. 26.

[53] Nazir, Moh. (2009), Metode Penelitian, Bogor: Ghalia Indonesia

[54] Neely, A., Adams, C., Kennerley, M. (2002), The Performance Prism: The Scorecard for Measuring and Managing Business Success, London: Financial Times Prentice Hall,

[55] Olamide, Olusanmi., Uwalomwa, Uwuigbe and Ranti, Uwuigbe Olubukunola. (2015). The Effect of Risk Management on Bank's Financial Performance in Nigeria. Journal of Accounting and Auditing: Research \& Practice. Vol. 2015 (2015), Article ID 239854, 7 pages

[56] Permatasari, Ika dan Retno Novitasary. (2014). Pengaruh Implementasi Good Corporate Governance terhadap Permodalan dan 
Kinerja Perbankan di Indonesia: Manajemen Risiko Sebagai Variabel Intervening. Jurnal Ekonomi Kuantitatif Terapan Vol. 7 No. $1^{\text {st }}$ February 2014

[57] Pertiwi, Tri Kartika dan Ferry Madi Ika Pratama. (2012). Pengaruh Kinerja Keuangan, Good Corporate Governance Terhadap Nilai Perusahaan Food and Beverage. Jurnal Manajemen dan Kewirausahaan, Vol.14, No. 2, September 2012: 118-127

[58] Poon, S; S.J. Taylor; dan C.W.R. Ward. (1992). Portfolio Diversification: A Pictorial Analysis of The UK Stock Market. Journal of Business Finance \& Accounting. Vol. 19 No. 1: 87-101.

[59] Priyatno Duwi,(2013), Analisis Korelasi,Regresi dan Multivariate dengan SPSS, Yogyakarta,Gaya Media.

[60] Randy, Vincentius dan Juniarti. (2013). Pengaruh Penerapan Good Corporate Governance Terhadap Nilai Perusahaan Yang Terdaftar di BEI 2007-2011. Business Accounting Review, Vol. 1, No. 2, 2013

[61] Rao, R. K. S., (1992), Financial Management Concept and Application, Second Edition, Singapore: MacMillan Publishing Company

[62] Rehman, A., \& Shah, S. Z. (2013). Board Independence, Ownership Structure and Firm Performance: Evidence from Pakistan. Interdisciplinary Journal of Contemporary Research in Business, 5(3), 2013, July, 832-835

[63] Retno M, Reny Dyah dan Denies Priantinah. (2012). Pengaruh Good Corporate Governance dan Pengungkapan Corporate Social Responsibility Terhadap Nilai Perusahaan (Studi Empiris Pada Perusahaan Yang Terdaftar di Bursa Efek Indonesia Periode 20072010). Jurnal Nominal / Volume I Nomor I / Tahun 2012

[64] Ridwan,(2008), Cara Menggunakan dan Memaknai Analisis Jalur, (Path Analysis), Bandung, Alfabeta

[65] Riyanto, Bambang. (2001). Dasar-Dasar Pembelanjaan Perusahaan, Edisi. Keempat, Cetakan Ketujuh, Yogyakarta: BPFE

[66] Riyanto, Bambang. (1995), Dasar-dasar pembelanjaan perusahaan, Edisi keempat,. Yogyakarta: Yayasan Penerbit Gajah Mada

[67] Ross, S.A., Westerfield, R.W., Jordan, B. D., (2004), Fundamentals of Corporate Finance. Sixth Edition, Singapore: McGraw-Hill Higher Education

[68] Rumondor, Regina., Maryam Mangantar dan Jacky S.B. Sumarauw. (2015). Pengaruh Struktur ModaL, Ukuran Perusahaan dan Risiko Perusahaan Terhadap Nilai Perusahaan Pada Sub Sektor Plastik dan Pengemasan di BEI. Jurnal EMBA Vol.3 No.3 Sept. 2015

[69] Saidi. (2004). Faktor-Faktor yang Mempengaruhi Struktur Modal pada Perusahaan Manufaktur Go Publik di BEJ Tahun 19972002, Jurnal Bisnis dan Ekonomi, Vol 11 No 1

[70] Smith, Michael P. (1996). Shareholder Activism by Institutional Investors: Evidence from Calpers, Journal of Finance 51, pp. 227252

[71] Somantri, Ating dan Muhidin, Sambas Ali. (2006). Aplikasi Statistika Dalam Penelitian, Bandung: Penerbit Pustaka Setia,

[72] Sony, Yuwono., Sukarno, Edy., dan Ichsan, Muhammad. (2007). Petunjuk Praktis Penyusunan Balanced Scorecard Menuju Organisasi yang Berfokus pada Strategi, Edisi 4, Jakarta: PT Gramedia Pustaka Utama, p 8

[73] Sucipto. (2003). Penilaian Kinerja Keuangan. Jurnal Akuntansi. Universitas Sumatra Utara. Medan

[74] Sudiyatno, Bambang dan Puspitasari, Elen. (2010). Pengaruh Kebijakan Perusahaan terhadap Nilai Perusahaan dengan Kinerja Perusahaan Sebagai Variabel Intervening (Studi pada Perusahaan Manufaktur di Bursa Efek Indonesia). Dinamika Keuangan dan Perbankan, Mei 2010, pp 1 - 22

[75] Sugiyono, (2010), Metode Penelitian Kuantitatif, Kualitatif, dan R \& D. Bandung: Alfabeta, p. 117

[76] Suharli, Michell, (2006). Akuntansi untuk Bisnis Jasa dan Dagang, Edisi Pertama. Yogyakarta: Graha Ilmu,

[77] Supriadi Edy,(2014), SPSS + Amos Perangkat Lunak Statistik, Mengolah Data Untuk Penelitian, Jakarta, InMedia.

[78] Suranta, Eddy dan Pratana Puspa Merdistusi. (2005). Pengaruh Good Corporate Governance Terhadap Praktek Manajemen Laba, Konferensi Nasional Akuntansi, Peran Akuntansi dalam Membangun Good Corporate Governance, Hal 1-8.

[79] Tahir, Izah Mohd., dan Ahmad Rizal Razali. (2011). The Relationship Between Enterprise Risk Management (ERM) and Firm Value: Evidence From Malaysian Public Listed Companies. International Journal of Economics and Management Sciences Vol. 1, No. 2, 2011, pp. 32-41

[80] Tandelilin, Eduardus. (2010). Portofolio dan Investasi Teori dan Aplikasi. Edisi Pertama. Yogyakarta: Kanisius

[81] The Indonesian Institute for Corporate Governance. (2006). www.iicg.org

[82] Todorović, Igor. (2013). Impact of Corporate Governance on Performance of Companies. Montenegrin Journal of Economics Vol. 9, No. 2 - Special Issue (May, 2013), 47-53

[83] Undang-Undang Republik Indonesia tentang Pasar Modal. UndangUndang No 8 Tahun 1995, LN No. 64 Tahun 1995, TLN No. 3608.

[84] Wardoyo dan Theodora Martina Veronica. (2013). Pengaruh Good Corporate Governance, Corporate Social Responsibility \& Kinerja Keuangan Terhadap Nilai Perusahaan. Jurnal Dinamika Manajemen Vol. 4, No. 2, 2013, pp: 132-149

[85] Weston, J Fred dan Thomas E. Copeland. (1996). Manajemen Keuangan. Edisi 8. Jilid 1. Jakarta: Erlangga

[86] Wibowo. (2013), Manajemen Kinerja. Edisi ketiga. Jakarta: PT. Rajagrafindo Persada, hh 10-11

[87] Woods, Margaret. 2007. Integrating Risk Management with Performance Management. Excellence in Leadership. Vol.2, 2007, pp.32-35

[88] Xie, Biao, Wallace N. Davidson dan Peter J. Dadalt. (2001). Earnings Management and Corporate governance: The Roles of the Board and the Audit Committee. Working Paper, pp.I-32

[89] Yuwono, Sony dkk. (2004), Petunjuk Praktis Penyusunan Balanced Scorecard: “Menuju Organisasi Yang Berfokus Pada Strategi, Jakarta:.PT. Gramedia Pustaka Utama, 